he National Institute of Standards and Technology was established in 1988 by Congress to "assist industry in the development of technology ... needed to improve product quality, to modernize manufacturing processes, to ensure product reliability ... and to facilitate rapid commercialization . . . of products based on new scientific discoveries."

NIST, originally founded as the National Bureau of Standards in 1901, works to strengthen U.S. industry's competitiveness; advance science and engineering; and improve public health, safety, and the environment. One of the agency's basic functions is to develop, maintain, and retain custody of the national standards of measurement, and provide the means and methods for comparing standards used in science, engineering, manufacturing, commerce, industry, and education with the standards adopted or recognized by the Federal Government.

As an agency of the U.S. Commerce Department's Technology Administration, NIST conducts basic and applied research in the physical sciences and engineering and performs related services. The Institute does generic and precompetitive work on new and advanced technologies. NIST's research facilities are located at Gaithersburg, MD 20899, and at Boulder, CO 80303. Major technical operating units and their principal activities are listed below. For more information contact the Public Inquiries Desk, 301-975-3058.

\section{Technology Services}

- Manufacturing Technology Centers Program

- Standards Services

- Technology Commercialization

- Measurement Services

- Technology Evaluation and Assessment

- Information Services

\section{Electronics and Electrical Engineering} Laboratory

- Microelectronics

- Law Enforcement Standards

- Electricity

- Semiconductor Electronics

- Electromagnetic Fields ${ }^{1}$

- Electromagnetic Technology

Chemical Science and Technology

Laboratory

- Biotechnology

- Chemical Engineering ${ }^{1}$

- Chemical Kinetics and Thermodynamics

- Inorganic Analytical Research

- Organic Analytical Research

- Process Measurements

- Surface and Microanalysis Science

- Thermophysics ${ }^{2}$

\section{Physics Laboratory}

- Electron and Optical Physics

- Atomic Physics

- Molecular Physics

- Radiometric Physics

- Quantum Metrology

- Ionizing Radiation

- Time and Frequency ${ }^{1}$

- Quantum Physics ${ }^{1}$
Manufacturing Engineering Laboratory

- Precision Engineering

- Automated Production Technology

- Robot Systems

- Factory Automation

- Fabrication Technology

Materials Science and Engineering Laboratory

- Intelligent Processing of Materials

- Ceramics

- Materials Reliability ${ }^{1}$

- Polymers

- Metallurgy

- Reactor Radiation

Building and Fire Research Laboratory

- Structures

- Building Materials

- Building Environment

- Fire Science and Engineering

- Fire Measurement and Research

Computer Systems Laboratory

- Information Systems Engineering

- Systems and Software Technology

- Computer Security

- Systems and Network Architecture

- Advanced Systems

Computing and Applied Mathematics Laboratory

- Applied and Computational Mathematics ${ }^{2}$

- Statistical Engineering ${ }^{2}$

- Scientific Computing Environments ${ }^{2}$

- Computer Services ${ }^{2}$

- Computer Systems and Communications ${ }^{2}$

- Information Systems 


\section{ISDN Conformance Testing Guidelines: \\ Guidelines for Implementors of ISDN Customer Premises Equipment to Conform to Both National ISDN-1 and North American ISDN Users' Forum Layer 3 Basic Rate Interface Basic Call Control Abstract Test Suites}

Leslie A. Collica and Dawn M. Hoffman

Advanced Systems Division

Computer Systems Laboratory

National Institute of Standards and Technology

Gaithersburg, MD 20899-0001

July 1994



U.S. Department of Commerce

Ronald H. Brown, Secretary

Technology Administration

Mary L. Good, Under Secretary for Technology

National Institute of Standards and Technology

Arati Prabhakar, Director 


\section{Reports on Computer Systems Technology}

The National Institute of Standards and Technology (NIST) has a unique responsibility for computer systems technology within the Federal government. NIST's Computer Systems Laboratory (CSL) develops standards and guidelines, provides technical assistance, and conducts research for computers and related telecommunications systems to achieve more effective utilization of Federal information technology resources. CSL's responsibilities include development of technical, management, physical, and administrative standards and guidelines for the cost-effective security and privacy of sensitive unclassified information processed in Federal computers. CSL assists agencies in developing security plans and in improving computer security awareness training. This Special Publication 823 series reports CSL research and guidelines to Federal agencies as well as to organizations in industry, government, and academia.

\section{National Institute of Standards and Technology Special Publication 823-6 Natl. Inst. Stand. Technol. Spec. Publ. 823-6, 27 pages (July 1994) CODEN: NSPUE2}

\section{U.S. GOVERNMENT PRINTING OFFICE WASHINGTON: 1994}




\title{
ISDN CONFORMANCE TESTING GUIDELINES -
}

Guidelines for Implementors of ISDN Customer Premises Equipment

To Conform to Both National ISDN-1 and North American ISDN Users' Forum

Layer 3 Basic Rate Interface Basic Call Control

Abstract Test Suites

\begin{abstract}
The following document is intended to provide information, as a supplement to the abstract test suites, to allow conformance to both the Bellcore National ISDN-1 (NI-1) and North American ISDN Users' Forum (NIUF) NIU.301 specifications for the ISDN Layer 3 Basic Rate Interface for Basic Call Control (user-side). It was developed to guide implementors in the design of customer premises equipment in a manner which would allow them to pass both the NI-1 and NIUF conformance tests. It may also be useful to vendors of test equipment, government procurement agents, and testing laboratories.
\end{abstract}

This testing guideline was developed by members of the North American ISDN Users' Forum's ISDN Conformance Testing Working Group and members of the Corporation for Open Systems' Task Force.

This document was approved in the North American ISDN Users' Forum as NIUF 429-94.

\section{KEYWORDS}

Abstract Test Suite, Basic Rate Interface, Conformance Testing, Customer Premises Equipment, Implementation Under Test, Integrated Services Digital Network, ISDN, Network Layer, Protocol Implementation Extra Information for Testing. 
NOTICE OF DISCLAIMER

THIS DOCUMENT CONTAINS NIUE CONFORMANCE TESTING GUIDELINES AS AGREED AMONG PARTICIPATING EXPERT TECHNICAL PERSONNEL ACCORDING TO THE TEXTS OF ISDN STANDARDS, CONFIGURATIONS AND DESCRIPTIONS THAT ARE INTENDED TO PROMOTE INTEROPERABILITY AND EFFICIENCY. THIS CONFORMANCE TESTING GUIDELINE WAS DEVELOPED AND APPROVED BY ORGANIZATIONS PARTICIPATING IN THE NORTH AMERICAN ISBN USERS' FORUM (NIUF) MEetings. NeITHER ThE NATIONAL INSTITUTE OF STANDARDS AND TECHNOLOGY (NIST) NOR ANY OF THE PARTICIPANTS IN THE NIUE MAKE ANY REPRESENTATION OR WARRANTY, EXPRESS OR IMPLIED WITH RESPECT TO THE SUFFICIENCY, ACCURACY, OR USE OF ANY INFORMATION OR OPINION CONTAINED HEREIN. THE USE OF THIS INFORMATION OR OPINION IS AT THE RISK OF THE USER. UNDER NO CIRCUMSTANCES SHALL NIST, OR ANY PARTICIPANT IN THE NIUF BE LIABLE FOR ANY DAMAGE OR INJURY INCURRED BY ANY PERSON ARISING OUT OF THE SUFFICIENCY, ACCURACY, OR USE OF ANY INFORMATION OR OPINION CONTAINED HEREIN.

iv 


\section{ACKNOWLEDGMENTS}

NIST would like to acknowledge the NIUF ISDN Conformance Testing (ICOT) Working Group, and especially the following individuals for their valuable technical contributions to this document:

List of Contributors

Organization





H. Gordon Brown . . . . . . . . . . . . . . . AT\&T Bell Laboratories

Yi Chin . . . . . . . . . . . . . . . . AT\&T Bell Laboratories

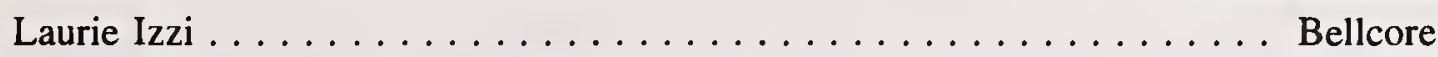

Chris Leising . . . . . . . . . . . . . . . . . . . Bellcore

Roxe Murray . . . . . . . . . . . . . . . . . . Northern Telecom

Pierre Prescott . . . . . . . . . . . . . . . . . . . . Tekelec

Suresh Ranganna . . . . . . . . . . . . . . . AT\&T Bell Laboratories

Kirby Spencer . . . . . . . . . . . . . Joint Interoperability Test Center

Michelle Stevens ..........................Bellcore

Al Vitenas . . . . . . . . . . . . . . . . . . . Bellcore 

INTRODUCTION $\ldots \ldots \ldots \ldots \ldots \ldots \ldots \ldots \ldots \ldots \ldots \ldots \ldots \ldots \ldots \ldots$

2

BACKGROUND

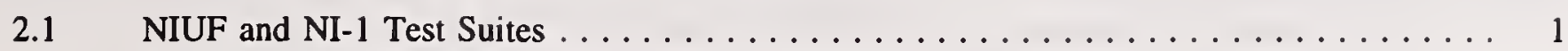

$2.2 \quad$ Contents of the Guideline $\ldots \ldots \ldots \ldots \ldots \ldots \ldots \ldots \ldots \ldots \ldots \ldots \ldots$

$3.1 \quad$ Unexpected or Unrecognized Messages $\ldots \ldots \ldots \ldots \ldots \ldots \ldots \ldots \ldots \ldots$

3.2 Nonmandatory Information Element Content Error $\ldots \ldots \ldots \ldots \ldots \ldots \ldots \ldots$



NIU.301 AND NI-1 INFORMATION ELEMENT OPTIONS $\ldots \ldots \ldots \ldots \ldots \ldots \ldots$



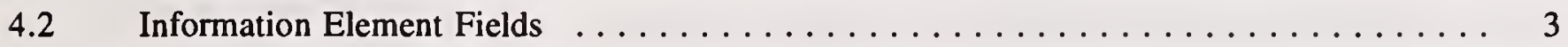

$5 \quad$ GENERAL CATEGORIES $\ldots \ldots \ldots \ldots \ldots \ldots \ldots \ldots \ldots \ldots \ldots \ldots$



5.2 Tests Unique to NIU.301 ... . . . . . . . . . . . . . . . . . 3

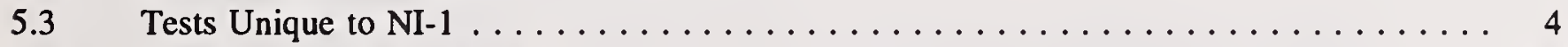

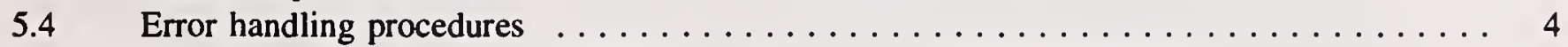

5.5 Optional and Uniquely Supported Messages $\ldots \ldots \ldots \ldots \ldots \ldots \ldots \ldots$

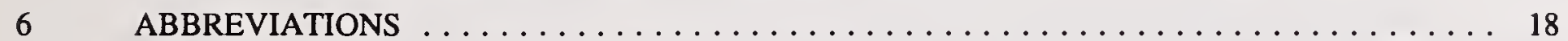




Table 1. MESSAGE OPTIONS -

Unexpected and Unrecognized Message Test Cases $\ldots \ldots \ldots \ldots \ldots \ldots \ldots \ldots \ldots \ldots$

Table 2. MESSAGE OPTIONS •

Nonmandatory Information Element (IE) Content Error Test Cases . . . . . . . . . . . 6

Table 3. MESSAGE OPTIONS - Miscellaneous Test Cases ..................... 7

Table 4. INFORMATION ELEMENT OPTIONS - Cause Value Test Cases $\ldots \ldots \ldots \ldots \ldots$

Table 5. TEST CASES UNIQUE TO NIU.301 ATS $\ldots \ldots \ldots \ldots \ldots \ldots \ldots \ldots \ldots \ldots$

Table 6. TEST CASES UNIQUE TO NI-1 ATS $\ldots \ldots \ldots \ldots \ldots \ldots \ldots \ldots \ldots \ldots \ldots \ldots \ldots$

Table 7. INFORMATION ELEMENTS - Specific to Messages $\ldots \ldots \ldots \ldots \ldots \ldots \ldots$

Table 8. INFORMATION ELEMENTS - Specific to Coding $\ldots \ldots \ldots \ldots \ldots \ldots \ldots \ldots \ldots$

Table 9. OPTIONAL AND UNIQUELY SUPPORTED MESSAGES - User to Network . . . . . . . 17 
The following document is intended to provide information, as a supplement to the abstract test suites (ATS), to allow conformance to both the Bellcore National ISDN-1 (NI-1) [1] and North American ISDN Users' Forum (NIUF) NIU.301 [2] specifications for the ISDN Layer 3 Basic Rate Interface for Basic Call Control (user-side). It was developed to guide implementors in the design of customer premises equipment (CPE) in a manner which would allow them to pass both the NI-1 and NIUF conformance tests $[3,4]$. It may also be useful to vendors of test equipment, government procurement agents, and testing laboratories.

This document emphasizes the common set of implementation options at the message and information element levels of the specifications. Only the protocol events which have multiple options are addressed. This Guideline covers the common set of options of the specifications for the basic call control test suites for Layer 3 .

Section 2 provides background and a description of this Guideline. Section 3 provides the selection of options at the message level which allows conformance to both specifications; section 4 provides selection at the information element level. Section 5 lists options for several general categories.

\section{BACKGROUND}

\subsection{NIUF and NI-1 Test Suites}

For conformance testing of ISDN basic rate access for NIUF and NI-1 specifications, comparison of the test suites showed:

- For Layer 1 - no difference between the test suites

- For Layer 2 - no difference between the test suites

- For Layer 3 - some difference between the test suites

- For Supplementary Services (SS) - 10 test suites for NI-1 SS; no test specification in NIUF.

For comparison of the Layer 3 basic call control specifications, several studies have addressed the question "What are the differences between the specifications?" During such a comparison for testing aspects, many similarities were found. The focus of the comparison was changed to address the question "Can CPE equipment be built to pass both NI- 1 and NIUF test suites for Layer 3?" The answer to the second question seems to be more useful information for vendors of $\mathrm{CPE}$ and test equipment, procurement agents, and testing laboratories. This Guideline answers the question by showing the common set of options of the specifications for the basic call control test suites for Layer 3 which would allow conformance to both NI-1 and NIUF.

\subsection{Contents of the Guideline}

The Guideline is divided into message options, information element options, and general categories. Within these sections, groups of tests cases are described with the "intersecting" option which, if implemented, allows CPE to pass both the NIUF and NI-1 test cases for that particular test event. The tables list the test cases, the test messages sent to the CPE under test, and the preferred CPE response, which is the common set options. The notations given in brackets in the tables refer to the related protocol specification section(s).

This Guideline covers the common set of implementation options at the message level and at the information element level. While there may be two options allowed by each specification (NIU.301 and NI-1) for a particular Layer 3 test event, there may be only one option which is the same for both - the "common set" of options.

The following table illustrates an example of a test message which is an "unexpected" message. 


\begin{tabular}{||c|c|c||}
\hline \multicolumn{3}{|c|}{ Allowed CPE Actions Upon Receipt of an Unexpected Message } \\
\hline \hline $\begin{array}{c}\text { NIUF } \\
\text { [NIU.301 section 5.8.4] }\end{array}$ & \multicolumn{1}{|c|}{ NI-1 } \\
[SR-1953 section 6.5.2] & $\begin{array}{c}\text { Guideline Recommendation } \\
\text { ("Common set" of options } \\
\text { to Pass NIUF and NI-1) }\end{array}$ \\
\hline $\begin{array}{l}\text { A) return a STATUS message } \\
\text { with cause \#97, 98, or 101, or }\end{array}$ & A) return a STATUS message, or & $\begin{array}{l}\text { Return a STATUS message with } \\
\text { cause \#97, 98, or 101 }\end{array}$ \\
\begin{tabular}{l} 
B) clear the call \\
\hline
\end{tabular} & C) ignore the message & \\
\hline
\end{tabular}

In this case, the Guideline would list only the "intersecting" option: return a STATUS message with cause \#97, 98, or 101. If STATUS with cause \#97, 98, or 101 is implemented, CPE could Pass both the NIUF (NIU.301) and NI- I test cases for unexpected messages. The Unexpected Messages in section 3.1.1 note the protocol sections of NIU.301 [NIU.301 5.8.4] and NI-1 [NI-1 6.5.2], refers to Table 1 for test cases, and describes the "common set" option as "in states U1-U10 - responding with a STATUS message with cause value 97, 98, or 101 would Pass both NIUF and NI-1 ATSs." In Table 1, the specific test cases and test messages are listed along with the preferred CPE response (the common set option).

\section{NIU.301 AND NI-1 MESSAGE OPTIONS}

This section lists the common set of message options for each particular protocol event which, if implemented, would allow CPE to pass both test suites.

\subsection{Unexpected or Unrecognized Messages}

3.1.1 For unexpected messages (except RELEASE or RELEASE COMPLETE) received in any state other than the Null state, specified in NIU.301 5.8.4 and NI-1 6.5.2:

- in states U1-U10 - responding with a STATUS message with cause value 97, 98, or 101 would Pass both NIUF and NI-1 ATSs.

- in states U11 and U19 - responding with either

1) a STATUS message (with cause value 97,98 , or 101 ), or

2) no response

would allow CPE to pass both NIUF and NI-1 ATSs.

Table 1 contains the list of these 45 unexpected messages test cases.

3.1.2 For unrecognized messages, as specified in NIU.301 5.8.4 and NI-1 6.5.2 - responding with a STATUS message with cause value 97,98 , or 101 would Pass both NIUF and NI-1 ATSs.

Table 1 contains the two unrecognized message type test cases.

\subsection{Nonmandatory Information Element Content Error}

For messages which contain a nonmandatory information element content error as specified in NIU.301 5.8.7.2 and NI-1 6.5.3.2: 
- Responding by "acting on the test message" (and not also sending a STATUS message), would Pass both NIUF and NI-1 ATSs.

Table 2 contains the list of 16 test cases.

\subsection{Other Message Option Test Cases}

- Responding according to the Preferred CPE Response in Table 3 would allow CPE to Pass both NIUF and NI-1 ATSs.

Table 3 contains the list of five test cases.

\section{$4 \quad$ NIU.301 AND NI-1 INFORMATION ELEMENT OPTIONS}

In this section, the information element (IE) options are listed which would allow CPE to pass both NI-1 and NIUF ATSs. The expected response at the message level is already the same in both NIU.301 and NI-1. The messages are listed in the tables for information only; it is the particular value or presence of an IE which is emphasized in the Preferred CPE Response column of the test case tables.

4.1 Cause values. In these cases, it is the particular cause value(s) which would allow CPE to pass both NI-1 and NIUF ATSs; the messages expected in response to the test events are already the same in both NIU.301 and NI1. The message and the particular cause value option(s) are listed as the preferred CPE response in Table 4. Although the NI-1 specification does not require specific cause values in these cases, in several cases, the intersecting cause value is also the "preferred" cause value specified in NI-1.

- Responding according to the Preferred CPE Response in Table 4 would Pass both NIUF and NI-1 ATSs. Table 4 contains the list of 25 test cases.

\subsection{Information Element Fields}

The results of the comparison of the Information Element fields for each message specified in NIU.301 and NI-1 are included in Tables 7 and 8 . Comments and recommendations for testing are included in the tables.

\section{GENERAL CATEGORIES}

5.1 Call Reference. NI-1 requires only the one octet call reference value, while NIU.301 allows for one or two octet call reference values. The addenda to NIU.301 [5] (June 1993) specifies only the one octet call reference value. No test cases are affected, since a three octet call reference value is used in the call reference length error test.

- Implementation of the single octet call reference would allow the CPE to pass both NI-1 and NIUF ATSs.

\subsection{Tests Unique to NIU.301}

Several of these tests are optional depending upon implementation capabilities. The test case selection is determined from answers to the NIU.301 Protocol Implementation Extra Information for Testing (PIXIT) questionnaire which is completed by a CPE vendor prior to testing. Table 5 contains the list of 17 test cases. 
5.3.1 STATUS ENQUIRY received in states other than U10. NIU.301 specifies only the occurrence of the STATUS ENQUIRY received in U10, and, therefore tests STATUS ENQUIRY only in state U10. NI-1 defines the behavior of STATUS ENQUIRY received in all states. Table 6 lists the nine test cases. The addenda to NIU.301 (June 1993) specifies the response to STATUS ENQUIRY in all states. The related STATUS ENQUIRY tests will be added to the next version of the NIU.301 test suites.

- Implementation of STATUS ENQUIRY procedures according to NI-1 would allow CPE to pass both NI-1 and NIUF ATSs.

5.3.2 Terminal Initialization. For basic call control, NI-1 requires terminal initialization, while NIU.301 does not require terminal initialization. For NIUF, it is currently outside of the scope of testing NIU.301. However, NIUF Implementation Agreement NIU89-311 [6] does provide optional procedures for terminal initialization. See Table 6 for the list of 20 test cases.

- Implementation of terminal initialization procedures according to NI-1 would allow CPE to pass both NI-1 and NIUF ATSs.

5.4 Error handling procedures. Although the error handling procedures referenced in NIU.301 section 5.8.4 are not defined in NI-1 (SR-NWT-001953), NI-1 does provide direction to the implementor by pointing to Section 5.8 of ANSI T1.607 [7]. The introduction in the Generic Guidelines for ISDN Terminal Equipment on Basic Access Interfaces revision 1 [1] states:

"Some ANSI requirements that do not impact terminal portability or compatibility with National ISDN-1 switches are not addressed in SR-NWT-001953. Specifically, procedures for handling error conditions defined in Section 5.8 of ANSI T1.607-1990 that do not affect terminal portability are not included in SR-NWT-001953. However, terminals will still be compatible with switches that conform to the NI-1 agreement if designed in accordance with SR-NWT-001953 plus the requirements in ANSI T1.607-1990 for procedures to handle error conditions that are not included in SR-NWT-001953."

- Implementing the error handling procedures as specified in NIU.301 section 5.8.4 would allow CPE to pass both NIUF and NI-1 ATSs.

\subsection{Optional and Uniquely Supported Messages.}

The list of optional messages is provided in Table 9 as information. The majority of these messages are for use for Supplementary Services. These messages do not impact the testing. 


\begin{tabular}{|c|c|c|}
\hline \multicolumn{3}{|c|}{$\begin{array}{l}\text { Table 1. MESSAGE OPTIONS - } \\
\text { Unexpected and Unrecognized Message Test Cases } \\
\text { [ NIU.301 5.8.4 / NI-1 6.5.2] }\end{array}$} \\
\hline Test Case \# (state $\mathrm{xx}$ ) & $\begin{array}{l}\text { Test Message } \\
\text { (Receive Event) }\end{array}$ & Preferred CPE Response \\
\hline NLxx_I01 (xx= U1,U4,U7,U8,U10) & ALERT & STATUS $($ cause $=97,98,101)$ \\
\hline NLxx_I01（xx= U11,U19) & ALERT & $\begin{array}{l}\text { STATUS } \text { (cause }=97,98,101 \text { ) } \\
\text { or No response }\end{array}$ \\
\hline NLxx_I03 (xx = U3,U4,U7,U8,U10) & CALL PROCEEDING & STATUS $($ cause $=97,98,101$ ) \\
\hline NLxx_I03（xx= U11,U19） & CALL PROCEEDING & $\begin{array}{l}\text { STATUS } \text { (cause }=97,98,101 \text { ) } \\
\text { or No response }\end{array}$ \\
\hline NLxx_I09 (xx= U1,U7,U8,U10) & PROGRESS & STATUS $($ cause $=97,98,101$ ) \\
\hline NLxx_I06 (xx= U11,U19) & PROGRESS & $\begin{array}{l}\text { STATUS } \text { (cause }=97,98,101 \text { ) } \\
\text { or No response }\end{array}$ \\
\hline NLxx_I09（xx= U1,U7,U8,U10) & CONNECT & STATUS (cause $=97,98,101$ ) \\
\hline NLxx_I09 (xx= U11,U19) & CONNECT & $\begin{array}{l}\text { STATUS } \text { (cause }=97,98,101 \text { ) } \\
\text { or No response }\end{array}$ \\
\hline NLxx_I11 ( $\mathrm{xx}=\mathrm{U} 2, \mathrm{U} 3, \mathrm{U} 4, \mathrm{U} 7, \mathrm{U} 8, \mathrm{U10})$ & $\begin{array}{l}\text { SETUP } \\
\text { ACKNOWLEDGE }\end{array}$ & STATUS $($ cause $=97,98,101)$ \\
\hline NLxx_I11 (xx= U11,U19) & $\begin{array}{l}\text { SETUP } \\
\text { ACKNOWLEDGE }\end{array}$ & $\begin{array}{l}\text { STATUS } \text { (cause }=97,98,101 \text { ) } \\
\text { or No response }\end{array}$ \\
\hline NLxx_I13 (xx= U1,U2,U3,U4,U7,U10) & $\begin{array}{l}\text { CONNECT } \\
\text { ACKNOWLEDGE }\end{array}$ & STATUS $($ cause $=97,98,101)$ \\
\hline NLxx_I13 (xx= U11,U19) & $\begin{array}{l}\text { CONNECT } \\
\text { ACKNOWLEDGE }\end{array}$ & $\begin{array}{l}\text { STATUS } \text { (cause }=97,98,101 \text { ) } \\
\text { or No response }\end{array}$ \\
\hline NLxx_I14（xx= U19） & DISCONNECT & $\begin{array}{l}\text { STATUS } \text { (cause }=97,98,101 \text { ) } \\
\text { or No response }\end{array}$ \\
\hline NLxx_I19 (xx= U1) & INFORMATION & STATUS (cause $=97,98,101$ ) \\
\hline NLxx_I14 (xx= U19) & INFORMATION & $\begin{array}{l}\text { STATUS } \text { (cause }=97,98,101 \text { ) } \\
\text { or No response }\end{array}$ \\
\hline NLxx_N120 (xx= U1,U10) & $\begin{array}{l}\text { Unrecognized message } \\
\text { type }\end{array}$ & STATUS $($ cause $=97,98,101)$ \\
\hline
\end{tabular}




\begin{tabular}{|c|c|c|}
\hline \multicolumn{3}{|c|}{$\begin{array}{l}\text { Table 2. MESSAGE OPTIONS - } \\
\text { Nonmandatory Information Element (IE) Content Error Test Cases } \\
\text { [ NIU.301 5.8.7.2 / NI-1 6.5.3. ] }\end{array}$} \\
\hline Test Case \# (state xx) & Test Message (Receive Event) & Preferred CPE Response \\
\hline$N L x x \_N 218(x x=U 1)$ & $\begin{array}{l}\text { CALL PROCEEDING (Progress } \\
\text { indicator IE length mismatch) }\end{array}$ & No response \\
\hline$N L x x \_N 219(x x=U 1)$ & $\begin{array}{l}\text { CALL PROCEEDING (Progress } \\
\text { indicator IE conflicting values) }\end{array}$ & No response \\
\hline NLxx_N224(xx=U0) & $\begin{array}{l}\text { CALL PROCEEDING (Signal IE } \\
\text { length mismatch) }\end{array}$ & No response \\
\hline NLxx_N222( $x x=U 4)$ & $\begin{array}{l}\text { PROGRESS (Signal IE length } \\
\text { mismatch) }\end{array}$ & No response \\
\hline NLxx_N224 (xx=U0) & $\begin{array}{l}\text { SETUP (Progress indicator IE } \\
\text { conflicting values) }\end{array}$ & $\begin{array}{l}\text { CALL PROCEEDING, } \\
\text { ALERT, or CONNECT }\end{array}$ \\
\hline NLxx_N225 (xx=U4) & $\begin{array}{l}\text { CONNECT (Progress indicator IE } \\
\text { length mismatch) }\end{array}$ & $\begin{array}{l}\text { CONNECT ACKNOWLEDGE } \\
\text { or No response }\end{array}$ \\
\hline NLxx_N226 (xx=U4) & $\begin{array}{l}\text { CONNECT (Progress indicator IE } \\
\text { conflicting values) }\end{array}$ & $\begin{array}{l}\text { CONNECT ACKNOWLEDGE } \\
\text { or No response }\end{array}$ \\
\hline NLxx_N227 (xx=U1) & $\begin{array}{l}\text { SETUP ACKNOWLEDGE (Progress } \\
\text { indicator IE length mismatch) }\end{array}$ & No response \\
\hline NLxx_N22: (xx=U0) & $\begin{array}{l}\text { SETUP ACKNOWLEDGE (Progress } \\
\text { indicator IE conflicting values) }\end{array}$ & No response \\
\hline$N L x x \_N 229(x x=U 8)$ & $\begin{array}{l}\text { CONNECT ACKNOWLEDGE } \\
\text { (Unrecognized nonmandatory IE error) }\end{array}$ & No response \\
\hline$N L x x \_N 230(x x=U 10)$ & $\begin{array}{l}\text { DISCONNECT } \\
\text { (User-user/Feature indicator length } \\
\text { mismatch) }\end{array}$ & RELEASE \\
\hline$N L x x \_N 231(x x=U 11)$ & $\begin{array}{l}\text { RELEASE (Cause IE length } \\
\text { mismatch) }\end{array}$ & RELEASE COMPLETE \\
\hline$N L x x \_N 233(x x=U 3)$ & $\begin{array}{l}\text { INFORMATION (Signal IE length } \\
\text { mismatch) }\end{array}$ & No response \\
\hline$N L x x \_N 238(x x=U 0)$ & $\begin{array}{l}\text { SETUP (Called party subaddress } \\
\text { conflicting values) }\end{array}$ & $\begin{array}{l}\text { CALL PROCEEDING, } \\
\text { ALERT, or CONNECT }\end{array}$ \\
\hline NLxx_N238 (xx=U0) & $\begin{array}{l}\text { SETUP (Low layer compatibility } \\
\text { length mismatch) }\end{array}$ & $\begin{array}{l}\text { CALL PROCEEDING, } \\
\text { ALERT, or CONNECT }\end{array}$ \\
\hline NLxx_N240 (xx=U0) & $\begin{array}{l}\text { SETUP (High layer compatibility } \\
\text { length mismatch) }\end{array}$ & $\begin{array}{l}\text { CALL PROCEEDING, } \\
\text { ALERT, or CONNECT }\end{array}$ \\
\hline
\end{tabular}




\begin{tabular}{|c|c|c|}
\hline Test Case \# & Test Message (Receive Event) & Preferred CPE Response \\
\hline NLU1_I14 & $\begin{array}{l}\text { DISCONNECT } \\
\text { [NIU.301 5.3.4.2 and 5.8.4/NI-1 } \\
6.4]\end{array}$ & RELEASE \\
\hline NLU0_N211"a & $\begin{array}{l}\text { Mandatory Information Element out } \\
\text { of sequence } \\
\text { [NIU.301 5.8.5.1/ ] }\end{array}$ & RELEASE COMPLETE (cause $=96$ ) \\
\hline NLU0_N234 & $\begin{array}{l}\text { SETUP with } \\
\text { Unrecognized nonmandatory IE } \\
\text { [NIU.301 5.8.7.1/NI-1 6.5.3.1] }\end{array}$ & $\begin{array}{l}\text { CALL_PROCEEDING, } \\
\text { or ALERT } \\
\text { or CONNECT }\end{array}$ \\
\hline NLU3_N234 & $\begin{array}{l}\text { ALERT with Unrecognized } \\
\text { nonmandatory IE } \\
\text { [NIU.301 } 5.8 .7 .1 / \text { NI-1 } \\
\text { 6.5.3.1] }\end{array}$ & No response \\
\hline NLU1_V243a & $\begin{array}{l}\text { B channel selection collision } \\
\text { [NIU.301 5.2.1] }\end{array}$ & $\begin{array}{l}\text { CALL_PROCEEDING, } \\
\text { or ALERT } \\
\text { or CONNECT }\end{array}$ \\
\hline
\end{tabular}




\begin{tabular}{|c|c|c|c|}
\hline \multirow{2}{*}{ Test Case \# } & \multirow{2}{*}{$\begin{array}{l}\text { Test Message } \\
\text { (Receive Event) }\end{array}$} & \multicolumn{2}{|c|}{ Preferred CPE Response } \\
\hline & & Message & Cause \\
\hline \multicolumn{4}{|c|}{ Call Reference Procedural Errors [ NIU.301 5.8.3.2(1) / NI-1 6.5.1 ] } \\
\hline NLU0_Iñ1 & ALERT (Unexpected) & RELEASE COMPLETE & 81 \\
\hline NLU0_I03 & CALL PROCEEDING (Unexpected) & RELEASE COMPLETE & 81 \\
\hline NLU0_IO & PROGRESS (Unexpected) & RELEASE COMPLETE & 81 \\
\hline NLU0_I09 & CONNECT (Unexpected) & RELEASE COMPLETE & 81 \\
\hline NLU0_I11 & SETUP ACKNOWLEDGE (Unexpected) & RELEASE COMPLETE & 81 \\
\hline NLU0_I13 & CONNECT ACKNOWLEDGE (Unexpected) & RELEASE COMPLETE & 81 \\
\hline NLU0_I14 & DISCONNECT (Unexpected) & RELEASE COMPLETE & 81 \\
\hline NLU0_I15 & RELEASE (Unexpected) & RELEASE COMPLETE & 81 \\
\hline NLU0_I14 & INFORMATION (Unexpected) & RELEASE COMPLETE & 81 \\
\hline NLU1_N213 & CALL PROCEEDING (Call reference value not in use) & RELEASE COMPLETE & 81 \\
\hline NLU8_N213 & CONNECT (Call reference value not in use) & RELEASE COMPLETE & 81 \\
\hline NLU10_N213 & DISCONNECT (Call reference value not in use) & RELEASE COMPLETE & 81 \\
\hline \multicolumn{4}{|c|}{ Mandatory Information Element (IE) Content Error [ NIU.301 5.8.6.2 ] } \\
\hline NLU1_N133 & $\begin{array}{l}\text { CALL PROCEEDING } \\
\text { (Channel identification with length mismatch) }\end{array}$ & STATUS or Clear Call ${ }^{b}$ & 100 \\
\hline NLU4_N135 & PROGRESS (Progress indicator length mismatch) & STATUS or Clear Call ${ }^{\mathrm{b}}$ & 100 \\
\hline NLU0_N139 & SETUP (Bearer capability undefined) & RELEASE COMPLETE & 100 \\
\hline NLUi_N133 & $\begin{array}{l}\text { SETUP (Channel identification with conflicting } \\
\text { values) }\end{array}$ & RELEASE COMPLETE & $\begin{array}{c}98 \text { or } \\
100\end{array}$ \\
\hline NLU1_N144 & $\begin{array}{l}\text { SETUP ACKNOWLEDGE } \\
\text { (Channel identification with length mismatch) }\end{array}$ & STATUS or Clear Call ${ }^{\mathrm{b}}$ & 100 \\
\hline NLU10_N159 & DISCONNECT (Cause length mismatch) & RELEASE & 100 \\
\hline NLU10_N160 & RELEASE (Cause length mismatch) & RELEASE COMPLETE & 100 \\
\hline
\end{tabular}


Table 4. Cause Value Test Cases (continued)

\begin{tabular}{|c|c|c|c|}
\hline \multirow{2}{*}{ Test Case \# } & \multirow{2}{*}{ Test Message } & \multicolumn{2}{|c|}{ Preferred CPE Response } \\
\hline & & Message & Cause \\
\hline \multicolumn{4}{|c|}{ Mandatory Information Element Missing [ NIU.301 5.8.6.1 ] } \\
\hline NLU1_N122 & CALL PROCEEDING & STATUS or Clear Call & 96 \\
\hline NLU4_N123 & PROGRESS & STATUS or Clear Call & 96 \\
\hline NLU0_N124 & SETUP & RELEASE COMPLETE & 96 \\
\hline NLU1_N126 & SETUP ACKNOWLEDGE & STATUS or Clear Call & 96 \\
\hline \multicolumn{4}{|c|}{ Cause values [ Other reference sections ] } \\
\hline NLU10_V18 & $\begin{array}{l}\text { STATUS ENQUIRY } \\
\text { [NIU.301 5.8.10/ NI-1 6.5.5] }\end{array}$ & $\begin{array}{l}\text { STATUS } \\
(\text { Call State }=\text { U10 })\end{array}$ & 30 \\
\hline \multicolumn{4}{|c|}{ Cause (CA) Value and Call State (CS) } \\
\hline NLU10_198 & $\begin{array}{l}\text { Data Link Establishment } \\
\text { [NIU.301 5.8.9] }\end{array}$ & STATUS & $\begin{aligned} \mathrm{CA} & =30 \\
\mathrm{CS} & =\mathrm{U} 10\end{aligned}$ \\
\hline $\begin{array}{l}\text { The preferre } \\
\text { Preferred CPE } \\
\text { The Clear C }\end{array}$ & $\begin{array}{l}\text { se value is the information em } \\
\text { nse is already the same in bot } \\
\text { essage is a DISCONNECT, RE }\end{array}$ & $\begin{array}{l}\text { this table. The Message o } \\
\text { ions. } \\
\text { RELEASE COMPLETE }\end{array}$ & \\
\hline
\end{tabular}




\begin{tabular}{|c|c|}
\hline $\begin{array}{l}\text { NIU.301 Test Case \# } \\
\text { (state } \mathbf{x x})\end{array}$ & $\begin{array}{l}\text { Test Message } \\
\text { (Event) }\end{array}$ \\
\hline NLU2_I01 & ALERT (Unexpected) [NIU.301 6.5.2] \\
\hline NLU2_I09 & CONNECT (Unexpected) [NIU.301 6.5.2] \\
\hline NLU4_N137 & $\begin{array}{l}\text { PROGRESS with mandatory Information Element (IE) error } \\
\text { (Progress indicator with conflicting values) [NIU.301 5.8.6.2] }\end{array}$ \\
\hline NLU3_N216 & $\begin{array}{l}\text { ALERT with nonmandatory IE error } \\
\text { (Progress indicator with length mismatch) [NIU.301 5.8.7.2] }\end{array}$ \\
\hline NLU3_N217 & $\begin{array}{l}\text { ALERT with nonmandatory IE error } \\
\text { (Progress indicator with conflicting values) [NIU.301 5.8.7.2] }\end{array}$ \\
\hline NLU2_N221 & $\begin{array}{l}\text { CALL PROCEEDING with nonmandatory IE error } \\
\text { (Channel identification with conflicting values) [NIU.301 5.8.7.2] }\end{array}$ \\
\hline NLU0_N223 & $\begin{array}{l}\text { SETUP with nonmandatory IE error } \\
\text { (User-user with length mismatch) [NIU.301 5.8.7.2] }\end{array}$ \\
\hline \multicolumn{2}{|r|}{ Optional Test Cases } \\
\hline NLU4_T192 & Timer T301 expiry (selected if T301_IMPLEMENTED) \\
\hline NLU2_T195 & Timer T304 expiry (selected if T304_IMPLEMENTED) \\
\hline NLU3_T200 & Timer T310 expiry (selected if T310_IMPLEMENTED) \\
\hline $\begin{array}{l}\text { NLxx_V241 } \\
\quad(\mathrm{xx}=\mathrm{U} 1, \mathrm{U} 2, \mathrm{U} 3 \\
\mathrm{U} 4, \mathrm{U} 10, \mathrm{U} 11, \mathrm{U} 19)\end{array}$ & $\begin{array}{l}\text { SETUP with Call Reference }(\mathrm{CR}) \text { flag }=0 \text {; } \mathrm{CR} \text { value in use } \\
\text { ( } 2 \text { simultaneous calls) } \\
\text { (selected if CPE supports simultaneous calls on two B-Channels) }\end{array}$ \\
\hline
\end{tabular}




\begin{tabular}{|c|c|}
\hline $\begin{array}{l}\text { NI-1 Test Case \# } \\
\text { (state } \mathbf{x x})\end{array}$ & $\begin{array}{l}\text { Test Message } \\
\text { (Event) }\end{array}$ \\
\hline $\begin{array}{l}\text { NLxx_V18* } \\
(\mathrm{xx}=\mathrm{U} 0, \mathrm{U} 1, \mathrm{U} 2, \mathrm{U} 3, \mathrm{U} 4 \\
\text { U7,U8,U11,U19) }\end{array}$ & STATUS ENQUIRY [NI-1 6.5.5] \\
\hline \multicolumn{2}{|r|}{ Terminal Initialization test cases in NI-1 } \\
\hline NLU0NI_V001 & $\begin{array}{l}\text { Verify that the IUT sends an INFOrmation message with Service Profile } \\
\text { Identification Information Element (SPI IE) = Service Profile Identifier (SPID) } \\
\text { when the Implementation Under Test (IUT) is in state UONI (not initialized). } \\
\text { [NI-1 8.5.2] }\end{array}$ \\
\hline NLU0S_V002 & $\begin{array}{l}\text { Verify that the IUT does not respond after receiving an INFO with the Endpoint } \\
\text { Identifier (EID) = User Service Identifier (USID), Terminal Identifier (TID) } \\
\text { when the IUT is in state UOS (IUT sent the SPID). [NI-1 8.5.2] }\end{array}$ \\
\hline NLU0IR_V002 & $\begin{array}{l}\text { Verify that the IUT does not respond after receiving an INFO with } \\
\text { EID=USID,TID when the IUT is in state UOIR (tester requested a SPID, SPID } \\
\text { sent). [NI-1 8.5.3] }\end{array}$ \\
\hline NLU0I_V002 & $\begin{array}{l}\text { Verify that the IUT does not respond after receiving an INFO with } \\
\text { EID=USID,TID when the IUT is in state UOI (initialized). [NI-1 8.5.3] }\end{array}$ \\
\hline NLU0S_V003 & $\begin{array}{l}\text { Verify that the IUT does not respond after receiving an INFO with Cause = } \\
\text { invalid IE contents (100) when the IUT is in state UOS (IUT sent the SPID). } \\
\text { [NI-1 8.5.2] }\end{array}$ \\
\hline NLU0IR_V003 & $\begin{array}{l}\text { Verify that the IUT does not respond after receiving an INFO with Cause = } \\
\text { invalid IE contents (100) when the IUT is in state UOIR (tester requested a } \\
\text { SPID). [NI-1 8.5.2] }\end{array}$ \\
\hline NLU0S_V004 & $\begin{array}{l}\text { Verify that the IUT sends an INFO with SPI=SPID after receiving an INFO with } \\
\text { an Information Request (IRQ) = prompt,TID when the IUT is in state UOS (IUT } \\
\text { sent the SPID). [NI-1 8.5.3] }\end{array}$ \\
\hline NLU0SR_V004 & $\begin{array}{l}\text { Verify that the IUT sends an INFO with SPI=SPID after receiving an INFO with } \\
\text { IRQ=prompt,TID when the IUT is in state UOSR (tester rejected the SPID). } \\
\text { [NI-1 8.5.3] }\end{array}$ \\
\hline NLU0I_V004 & $\begin{array}{l}\text { Verify that the IUT sends an INFO with SPI=SPID after receiving an INFO with } \\
\text { IRQ=prompt,TID when the IUT is in state UOI (Initialized). [NI-1 8.5.3] }\end{array}$ \\
\hline NLU0S_V005 & $\begin{array}{l}\text { Verify that the IUT does not respond after receiving an INFO with } \\
\text { IRQ=Complete, EID=USID,TID when the IUT is in state U0S (IUT sent the } \\
\text { SPID). [NI-1 8.5.3] }\end{array}$ \\
\hline NLU0IR_V005 & $\begin{array}{l}\text { Verify that the IUT does not respond after receiving an INFO with } \\
\text { IRQ=Complete, EID=USID,TID when the IUT is in state UOIR (tester requested } \\
\text { a SPID, SPID sent). [NI-1 8.5.3] }\end{array}$ \\
\hline
\end{tabular}




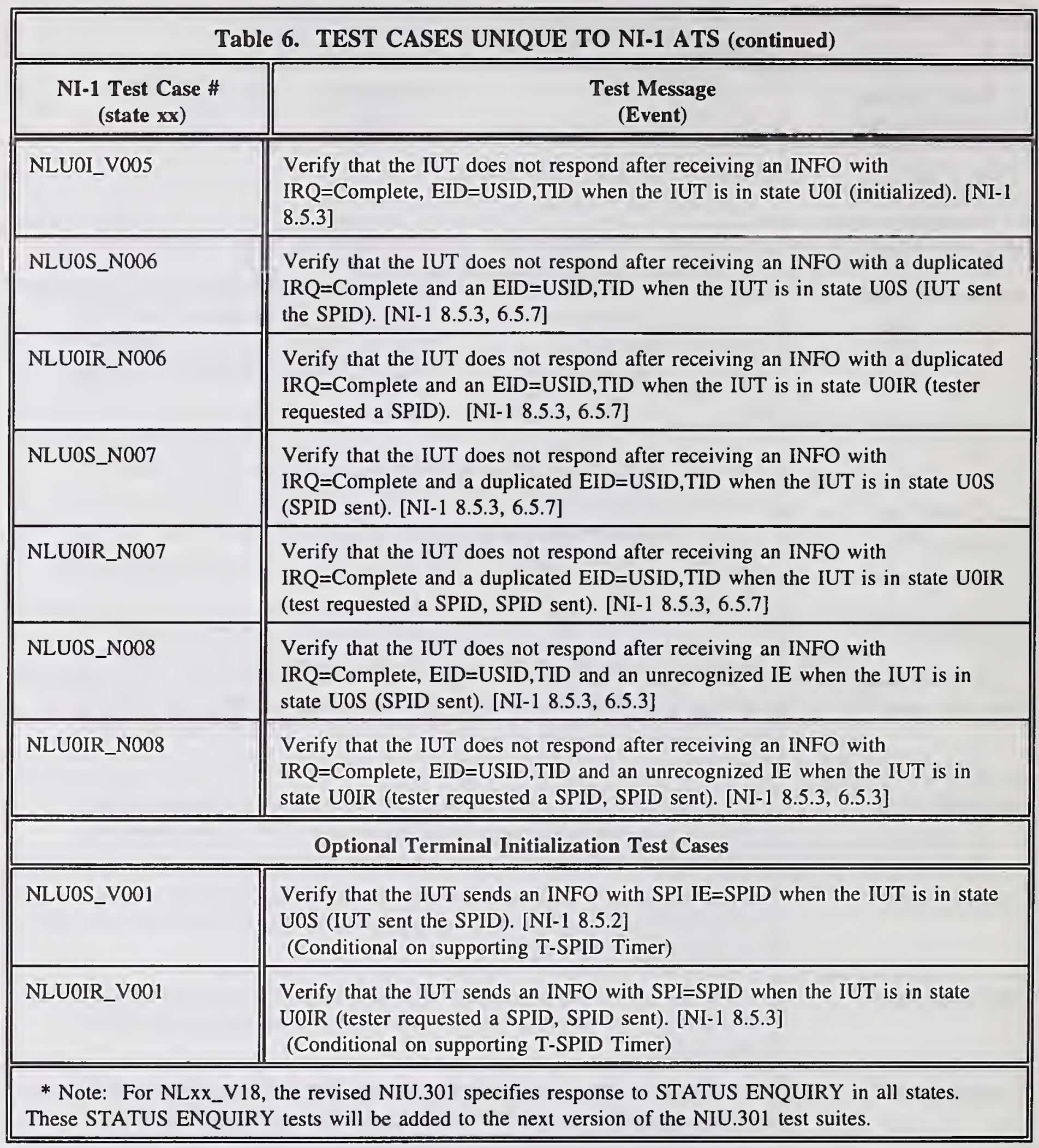




\begin{tabular}{|c|c|c|c|}
\hline Information Element & NIU.301 & NI-1 & Recommendation \\
\hline \multicolumn{4}{|c|}{ ALERTING - User to Network } \\
\hline $\begin{array}{l}\text { Channel } \\
\text { identification }\end{array}$ & $\begin{array}{l}\text { Either preferred } \\
\text { or exclusive B } \\
\text { channel allowed }\end{array}$ & Exclusive B channel & $\begin{array}{l}\text { For testing, use } \\
\text { exclusive B channel. }\end{array}$ \\
\hline User-user & Optional & Not supported & $\begin{array}{l}\text { No impact to testing - } \\
\text { this IE is allowed in } \\
\text { both ATSs. }\end{array}$ \\
\hline \multicolumn{4}{|c|}{ CALL PROCEEDING - User to Network } \\
\hline Progress indicator & Supported & Not supported & $\begin{array}{l}\text { For testing, recommend } \\
\text { not sending Progress } \\
\text { indicator. }\end{array}$ \\
\hline \multicolumn{4}{|c|}{ CONNECT - User to Network } \\
\hline User-user & Optional & Future & $\begin{array}{l}\text { No impact on testing - } \\
\text { allowed in both ATSs. }\end{array}$ \\
\hline \multicolumn{4}{|c|}{ DISCONNECT - User to Network } \\
\hline User-user & Optional & Future & $\begin{array}{l}\text { Recommend not } \\
\text { including this IE in user } \\
\text { to network direction. }\end{array}$ \\
\hline \multicolumn{4}{|c|}{ INFORMATION - User to Network } \\
\hline Keypad facility & Mandatory & $0.1^{*}$ & $\begin{array}{l}\text { Used for supplementary } \\
\text { services in NI-1 - for } \\
\text { basic call, recommend } \\
\text { using Keypad facility, } \\
\text { rather than Called Party } \\
\text { Number. }\end{array}$ \\
\hline Feature activation & Not supported & $\begin{array}{c}\text { For supplementary } \\
\text { services }\end{array}$ & $\begin{array}{l}\text { No impact on testing - } \\
\text { used for Supplementary } \\
\text { Services. }\end{array}$ \\
\hline Service Profile ID & Not supported & For initialization & $\begin{array}{l}\text { See section } 5.3 .2 \text { of this } \\
\text { Guideline. }\end{array}$ \\
\hline $\begin{array}{l}\text { Called party } \\
\text { number }\end{array}$ & Not supported & $0.1^{*}$ & $\begin{array}{l}\text { Used for supplementary } \\
\text { services in NI-1 - for } \\
\text { basic call, recommend } \\
\text { using keypad facility, } \\
\text { rather than Called Party } \\
\text { Number }\end{array}$ \\
\hline
\end{tabular}




\begin{tabular}{|c|c|c|c|}
\hline Information Element & NIU.301 & NI-1 & Recommendation \\
\hline \multicolumn{4}{|c|}{ INFORMATION - Network to User } \\
\hline Progress indicator $(\mathrm{PI})$ & Not supported & $\begin{array}{l}\text { Allowed, but not } \\
\text { required }\end{array}$ & $\begin{array}{l}\text { IUT should be able to handle } \\
\text { receipt of PI. For NIU. } 301 \text {, treat } \\
\text { as an unrecognized non- } \\
\text { mandatory IE and ignore PI, but } \\
\text { process the information message. }\end{array}$ \\
\hline \multicolumn{4}{|c|}{ RELEASE - User to Network } \\
\hline User-user & Optional & Future & $\begin{array}{l}\text { Recommend not including this IE } \\
\text { in user to network direction }\end{array}$ \\
\hline \multicolumn{4}{|c|}{ RELEASE COMPLETE - User to Network } \\
\hline User-user & Optional & Future & $\begin{array}{l}\text { Recommend not including this IE } \\
\text { in user to network direction }\end{array}$ \\
\hline \multicolumn{4}{|l|}{ SETUP - User to Network } \\
\hline $\begin{array}{l}\text { Channel } \\
\text { identification }\end{array}$ & $\begin{array}{l}\text { Either preferred } \\
\text { or exclusive B } \\
\text { channel allowed }\end{array}$ & $\begin{array}{c}\text { Exclusive B } \\
\text { channel allowed }\end{array}$ & $\begin{array}{l}\text { For testing, use exclusive B } \\
\text { channel }\end{array}$ \\
\hline Feature activation & Not supported & $\begin{array}{c}\text { For } \\
\text { supplementary } \\
\text { services }\end{array}$ & $\begin{array}{l}\text { Not used for basic call - for } \\
\text { supplementary services }\end{array}$ \\
\hline User-user & Optional & Future & $\begin{array}{l}\text { No impact on testing - allowed in } \\
\text { both ATSs }\end{array}$ \\
\hline Call appearance & Not supported & $\begin{array}{c}\text { For } \\
\text { supplementary } \\
\text { services }\end{array}$ & $\begin{array}{l}\text { Not used for basic call - for } \\
\text { supplementary services }\end{array}$ \\
\hline
\end{tabular}




\begin{tabular}{|c|c|c|c|}
\hline Information Element & NIU.301 & NI-1 & Comments \\
\hline Call reference & 1 or 2 octets & 1 octet & $\begin{array}{l}\text { See section } 5.1 \text { of this } \\
\text { Guideline. }\end{array}$ \\
\hline $\begin{array}{l}\text { Bearer capability } \\
\text { octet } 3 \text { : Information } \\
\text { transfer capability }\end{array}$ & $\begin{array}{l}\text { Restricted digital } \\
\text { information allowed }\end{array}$ & $\begin{array}{l}\text { Restricted digital } \\
\text { information not allowed }\end{array}$ & $\begin{array}{l}\text { For testing, choose a } \\
\text { supported information } \\
\text { transfer capability } \\
\text { other than restricted } \\
\text { digital information. }\end{array}$ \\
\hline $\begin{array}{l}\text { Bearer capability } \\
\text { octet } 5 \text { : User } \\
\text { information Layer } 1\end{array}$ & $\begin{array}{l}\text { G. } 722 \text { and X. } 31 \text { HDLC } \\
\text { flag stuffing are } \\
\text { allowed }\end{array}$ & $\begin{array}{l}\text { G.722 and X.31 HDLC } \\
\text { flag stuffing are not } \\
\text { allowed }\end{array}$ & $\begin{array}{l}\text { For testing, choose } \mu- \\
\text { law or rate adaption. }\end{array}$ \\
\hline $\begin{array}{l}\text { Called party number } \\
\text { octet 3: Type of } \\
\text { number }\end{array}$ & $\begin{array}{l}\text { Network Specific } \\
\text { Number is not allowed }\end{array}$ & $\begin{array}{l}\text { Network Specific } \\
\text { Number is allowed }\end{array}$ & $\begin{array}{l}\text { For testing, use other } \\
\text { than network specific } \\
\text { number. }\end{array}$ \\
\hline $\begin{array}{l}\text { Calling party number } \\
\text { octet } 3 \text { : Type of } \\
\text { number and Numbering } \\
\text { Plan Identification }\end{array}$ & $\begin{array}{l}\text { For user to network, } \\
\text { local (subscriber). } \\
\text { national and others are } \\
\text { allowed. }\end{array}$ & $\begin{array}{l}\text { For user to network, } \\
\text { for type of number and } \\
\text { numbering plan, either } \\
\text { local or national and } \\
\text { ISDN numbering plan is } \\
\text { allowed. }\end{array}$ & $\begin{array}{l}\text { For testing, for type of } \\
\text { number and } \\
\text { numbering plan, use } \\
\text { local (subscriber) or } \\
\text { national and ISDN } \\
\text { numbering plan. }\end{array}$ \\
\hline $\begin{array}{l}\text { Cause } \\
\text { octet 4: Cause value }\end{array}$ & Different values & Different values & $\begin{array}{l}\text { See section } 4.1 \text { of this } \\
\text { Guideline. }\end{array}$ \\
\hline $\begin{array}{l}\text { High layer compatibility } \\
\text { octet 4a: Extended } \\
\text { high-layer character- } \\
\text { istics identification }\end{array}$ & $\begin{array}{l}\text { Extended Higher Layer } \\
\text { characteristics is not } \\
\text { allowed }\end{array}$ & $\begin{array}{l}\text { Extended Higher Layer } \\
\text { characteristics is } \\
\text { allowed }\end{array}$ & No impact on testing. \\
\hline $\begin{array}{l}\text { Low layer compatibility } \\
\text { octet 3: Coding } \\
\text { standard }\end{array}$ & $\begin{array}{l}\text { Codepoint ' } 01 \text { ' not } \\
\text { supported. }\end{array}$ & $\begin{array}{l}\text { Supports codepoint '01' } \\
\text { (other international } \\
\text { standard) }\end{array}$ & No impact on testing. \\
\hline $\begin{array}{l}\text { Low layer compatibility } \\
\text { octet 3: Information } \\
\text { transfer capability }\end{array}$ & Video not allowed & Video allowed & No impact on testing. \\
\hline $\begin{array}{l}\text { Low layer compatibility } \\
\text { octet 3a: Negotiation } \\
\text { indicator }\end{array}$ & $\begin{array}{l}\text { Out-band negotiation } \\
\text { not allowed }\end{array}$ & $\begin{array}{l}\text { Out-band negotiation } \\
\text { allowed }\end{array}$ & No impact on testing. \\
\hline \multirow{2}{*}{$\begin{array}{l}\text { Low layer compatibility } \\
\text { octets } 4 \text { and } 4 \mathrm{~b} \text { : } \\
\text { Information transfer } \\
\text { rate }\end{array}$} & $\begin{array}{l}\text { Codepoint ' } 10001 \text { ' not } \\
\text { supported }\end{array}$ & $\begin{array}{l}\text { Supports codepoint } \\
\text { '10001' (128 kbps) }\end{array}$ & \multirow[t]{2}{*}{ No impact on testing. } \\
\hline & $\begin{array}{l}\text { Supports codepoint } \\
\text { ' } 10100 \text { ' (1472 kbps-- } \\
\text { national standard only) }\end{array}$ & $\begin{array}{l}\text { Codepoint '10100' not } \\
\text { supported }\end{array}$ & \\
\hline
\end{tabular}




\begin{tabular}{|c|c|c|c|}
\hline Information Element & NIU.301 & $\mathrm{NI}-1$ & Comments \\
\hline $\begin{array}{l}\mathrm{LC} \text { Coctets } 4 \text { and } \\
4 \text { b:informa- } \\
\text { tion transfer rate (cont.) }\end{array}$ & $\begin{array}{l}\text { Codepoint '10111' not } \\
\text { supported }\end{array}$ & $\begin{array}{l}\text { Supports codepoint '10111' } \\
\text { (1920 kbps) }\end{array}$ & $\begin{array}{l}\text { No impact on } \\
\text { testing. }\end{array}$ \\
\hline \multirow{3}{*}{$\begin{array}{l}\text { Low layer compatibility } \\
\text { octet } 5 \text { : User } \\
\text { information layer } 1 \\
\text { protocol }\end{array}$} & $\begin{array}{l}\text { Codepoint '00011' not } \\
\text { supported }\end{array}$ & $\begin{array}{l}\text { Supports codepoint '00011' } \\
\text { (G.711 A-law) }\end{array}$ & \multirow{3}{*}{$\begin{array}{l}\text { No impact on } \\
\text { testing. }\end{array}$} \\
\hline & $\begin{array}{l}\text { Codepoint '00100' not } \\
\text { supported }\end{array}$ & $\begin{array}{l}\text { Supports codepoint '00100' } \\
\text { (G.721 } 32 \mathrm{kbps} / \mathrm{ADPCM} \text { ) }\end{array}$ & \\
\hline & $\begin{array}{l}\text { Codepoint '00110' not } \\
\text { supported }\end{array}$ & $\begin{array}{l}\text { Supports codepoint '00110' } \\
\text { (H.261 for } 384 \text { kbps video) }\end{array}$ & \\
\hline $\begin{array}{l}\text { Low layer compatibility } \\
\text { octet } 5 \text { a: Synchronous/ } \\
\text { asynchronous }\end{array}$ & $\begin{array}{l}\text { Difference in content of } \\
\text { note }\end{array}$ & $\begin{array}{l}\text { Difference in content of } \\
\text { note }\end{array}$ & $\begin{array}{l}\text { No impact on } \\
\text { testing. }\end{array}$ \\
\hline $\begin{array}{l}\text { Low layer compatibility } \\
\text { octet } 5 \mathrm{~b} \text { : In-band/ } \\
\text { out of band negotiation }\end{array}$ & $\begin{array}{l}\text { Codepoint ' } 0 \text { ' not } \\
\text { supported }\end{array}$ & $\begin{array}{l}\text { Supports codepoint ' } 0 \text { ' } \\
\text { (negotiation done with user } \\
\text { information messages) }\end{array}$ & $\begin{array}{l}\text { No impact on } \\
\text { testing. }\end{array}$ \\
\hline $\begin{array}{l}\text { Low layer compatibility } \\
\text { octet } 5 \mathrm{c} \text { : Number of } \\
\text { stop bits, number of } \\
\text { data bits excluding parity, } \\
\text { parity information }\end{array}$ & Usage note provided & No note present & $\begin{array}{l}\text { No impact on } \\
\text { testing. }\end{array}$ \\
\hline \multirow{3}{*}{$\begin{array}{l}\text { Low layer compatibility } \\
\text { octet 6: User } \\
\text { information layer } 2 \\
\text { protocol }\end{array}$} & $\begin{array}{l}\text { Codepoint '01110' not } \\
\text { supported }\end{array}$ & $\begin{array}{l}\text { Supports codepoint '01110' } \\
\text { (Q.922) }\end{array}$ & \multirow{3}{*}{$\begin{array}{l}\text { No impact on } \\
\text { testing. }\end{array}$} \\
\hline & $\begin{array}{l}\text { Codepoint '01111' not } \\
\text { supported }\end{array}$ & $\begin{array}{l}\text { Supports codepoint ' } 01111 \text { ' } \\
\text { (Q.922 core aspects) }\end{array}$ & \\
\hline & $\begin{array}{l}\text { Codepoint '10001' not } \\
\text { supported }\end{array}$ & $\begin{array}{l}\text { Supports codepoint '10001' } \\
\text { (T.90) }\end{array}$ & \\
\hline \multirow{2}{*}{$\begin{array}{l}\text { Low layer compatibility } \\
\text { octet } 7 \text { : User } \\
\text { information layer } 3 \\
\text { protocol }\end{array}$} & $\begin{array}{l}\text { Codepoint '00010' not } \\
\text { supported }\end{array}$ & $\begin{array}{l}\text { Supports codepoint '00010' } \\
\text { (Q.931) }\end{array}$ & \multirow{2}{*}{$\begin{array}{l}\text { No impact on } \\
\text { testing. }\end{array}$} \\
\hline & $\begin{array}{l}\text { Codepoint '00101' not } \\
\text { supported }\end{array}$ & $\begin{array}{l}\text { Supports codepoint '00101' } \\
\text { (T.90) }\end{array}$ & \\
\hline $\begin{array}{l}\text { Progress indicator } \\
\text { octet 3: Location }\end{array}$ & $\begin{array}{l}\text { General location } \\
\text { international is not } \\
\text { supported. }\end{array}$ & $\begin{array}{l}\text { General location } \\
\text { international is supported. }\end{array}$ & $\begin{array}{l}\text { No impact on } \\
\text { testing. }\end{array}$ \\
\hline $\begin{array}{l}\text { Signal } \\
\text { octet 3: Signal value }\end{array}$ & $\begin{array}{l}\text { Network Specific Signal } \\
\text { value is not supported. }\end{array}$ & $\begin{array}{l}\text { Network Specific Signal } \\
\text { value is supported. }\end{array}$ & $\begin{array}{l}\text { No impact on } \\
\text { testing. }\end{array}$ \\
\hline
\end{tabular}




\begin{tabular}{||l|c|c|c||}
\hline \multicolumn{2}{||c|}{ Table 9. OPTIONAL AND UNIQUELY SUPPORTED MESSAGES - User to Network } \\
(For Information - No Impact on Testing)
\end{tabular}

17 
ANSI American National Standards Institute

ATS Abstract Test Suite

BRI Basic Rate Interface

COS Corporation for Open Systems

CPE Customer Premises Equipment

EID Endpoint Identifier

ICOT ISDN Conformance Testing Working Group

IE Information Element

INFO Information

IRQ Information Request

ISDN Integrated Services Digital Network

IUT Implementation Under Test

kbps kilobits per second

NI-1 National ISDN-1 (Bellcore CPE Guidelines)

NIUF North American ISDN Users' Forum

PIXIT Protocol Implementation Extra Information for Testing

SPID Service Profile Identifier

SPI Service Profile Identification

SS Supplementary Services

USID User Service Identifier

TID Terminal Identifier

U1,U19 User states U1, U19 
[1] Bellcore SR-NWT-001953, Generic Guidelines for ISDN Terminal Equipment on Basic Access Interfaces, Issue 1, June 1991, plus revision 1, December 1991.

[2] NIU 90-301, Implementation Agreement of the North American ISDN Users' Forum, Layer 3 Signalling Specification for the Minimal Set of Circuit Switched Bearer Services for the ISDN Basic Rate Interface/Class I, 1990.

[3] National ISDN-1 BRI Basic Call Control Abstract Test Suite for user-side conformance testing, Corporation for Open Systems NI-1 Task Force (COS/ATS-93/001).

[4] North American ISDN Users's Forum NIUF 413-92, Layer 3 Network Layer - Circuit Switch Call Control, Basic Rate Interface-Class I, User Side Abstract Test Suite (Version 1.2) June 1993.

[5] NIUF 419-93, Implementation Agreement of the North American ISDN Users' Forum, Addenda to NIU 301 (June 1993).

[6] NIU 89-311, Implementation Agreement of the North American ISDN Users' Forum, Generic Procedures for the Control of ISDN Supplementary Services - Basic Rate Interface/Class I.

[7] ANSI T1.607-1990, Telecommunications - Integrated Services Digital Network (ISDN) - Digital Subscriber Signalling System Number 1 (DSS1) - Layer 3 Signalling Specification for Circuit Switched Bearer Service.

a. ANSI Documents can be obtained by contacting the American National Standards Institute, 11 West 42nd Street, New York, NY 10036.

b. Bellcore Documents can be obtained by calling 1-800-521-CORE (2673) or by sending fax to (908) 336-2559.

c. COS Documents can be obtained by contacting Robert Blackshaw, COS, 8260 Willow Oaks Corporate Drive, Suite 700, Fairfax, VA 22031.

d. NIUF(NIU) Documents can be obtained by contacting: NIUF Administrator, NIST, Building 223, Room B-364, Gaithersburg, MD 20899. 



\section{ANNOUNCEMENT OF NEW PUBLICATIONS ON INTEGRATED SERVICES DIGITAL NETWORK}

Superintendent of Documents

Government Printing Office

Washington, DC 20402

\section{Dear Sir:}

Please add my name to the announcement list of new publications to be issued in the series: National Institute of Standards and Technology Special Publication 823-.

Name

Company

Address

City State Zip Code

(Notification key N-503) 



Journal of Research of the National Institute of Standards and Technology-Reports NIST research and development in those disciplines of the physical and engineering sciences in which the Institute is active. These include physics, chemistry, engineering, mathematics, and computer sciences. Papers cover a broad range of subjects, with major emphasis on measurement methodology and the basic technology underlying standardization. Also included from time to time are survey articles on topics closely related to the Institute's technical and scientific programs. Issued six times a year.

\section{Nonperiodicals}

Monographs-Major contributions to the technical literature on various subjects related to the Institute's scientific and technical activities.

Handbooks-Recommended codes of engineering and industrial practice (including safety codes) developed in cooperation with interested industries, professional organizations, and regulatory bodies.

Special Publications - Include proceedings of conferences sponsored by NIST, NIST annual reports, and other special publications appropriate to this grouping such as wall charts, pocket cards, and bibliographies.

Applied Mathematics Series-Mathematical tables, manuals, and studies of special interest to physicists, engineers, chemists, biologists, mathematicians, computer programmers, and others engaged in scientific and technical work.

National Standard Reference Data Series - Provides quantitative data on the physical and chemical properties of materials, compiled from the world's literature and critically evaluated. Developed under a worldwide program coordinated by NIST under the authority of the National Standard Data Act (Public Law 90-396). NOTE: The Journal of Physical and Chemical Reference Data (JPCRD) is published bimonthly for NIST by the American Chemical Society (ACS) and the American Institute of Physics (AIP). Subscriptions, reprints, and supplements are available from ACS, 1155 Sixteenth St., NW, Washington, DC 20056.

Building Science Series-Disseminates technical information developed at the Institute on building materials, components, systems, and whole structures. The series presents research results, test methods, and performance criteria related to the structural and environmental functions and the durability and safety characteristics of building elements and systems.

Technical Notes-Studies or reports which are complete in themselves but restrictive in their treatment of a subject. Analogous to monographs but not so comprehensive in scope or definitive in treatment of the subject area. Often serve as a vehicle for final reports of work performed at NIST under the sponsorship of other government agencies.

Voluntary Product Standards - Developed under procedures published by the Department of Commerce in Part 10, Title 15, of the Code of Federal Regulations. The standards establish nationally recognized requirements for products, and provide all concerned interests with a basis for common understanding of the characteristics of the products. NIST administers this program in support of the efforts of private-sector standardizing organizations.

Consumer Information Series - Practical information, based on NIST research and experience, covering areas of interest to the consumer. Easily understandable language and illustrations provide useful background knowledge for shopping in today's technological marketplace. Order the above NIST publications from: Superintendent of Documents, Government Printing Office, Washington, DC 20402.

Order the following NIST publications-FIPS and NISTIRs - from the National Technical Information Service, Springfield, VA 22161.

Federal Information Processing Standards Publications (FIPS PUB)-Publications in this series collectively constitute the Federal Information Processing Standards Register. The Register serves as the official source of information in the Federal Government regarding standards issued by NIST pursuant to the Federal Property and Administrative Services Act of 1949 as amended, Public Law 89-306 (79 Stat. 1127), and as implemented by Executive Order 11717 (38 FR 12315, dated May 11, 1973) and Part 6 of Title 15 CFR (Code of Federal Regulations).

NIST Interagency Reports (NISTIR) - A special series of interim or final reports on work performed by NIST for outside sponsors (both government and non-government). In general, initial distribution is handled by the sponsor; public distribution is by the National Technical Information Service, Springfield, VA 22161, in paper copy or microfiche form. 


\section{U.S. Department of Commerce}

National Institute of Standards and Technology

Gaithersburg, MD 20899-0001

Official Business

Penalty for Private Use $\$ 300$ 